\title{
Small Rodents Fleas from the Bubonic Plague Focus Located in the Serra dos Órgãos Mountain Range, State of Rio de Janeiro, Brazil
}

\author{
Raimundo Wilson de Carvalho/ ${ }^{+}$, Nicolau Maués Serra-Freire/ ${ }^{++}$, \\ Pedro Marcos Linardi*/++, Adilson Benedito de Almeida**, \\ Jeronimo Nunes da Costa**
}

\begin{abstract}
Laboratório de Ixodides, Departamento de Entomologia, Instituto Oswaldo Cruz-Fiocruz, Av. Brasil 4365, 21045-900 Rio de Janeiro, RJ, Brasil *Departamento de Parasitologia, ICB, Universidade Federal de Minas Gerais, Belo Horizonte, MG, Brasil **Serviço de Operações de Campo, Fundação Nacional de Saúde, Rio de Janeiro, RJ, Brasil
\end{abstract}

Eleven species of fleas were collected from 601 small rodents, from November 1995 to October 1997, in areas of natural focus of bubonic plague, including the municipalities of Nova Friburgo, Sumidouro and Teresópolis, State of Rio de Janeiro, Brazil. Among 924 fleas collected, Polygenis (Polygenis) rimatus (Rhopalopsyllidae) was the predominant species regarding the frequency, representing $41.3 \%$ (N:382), followed by P. (Neopolygenis) pradoi, representing 20\% (N:185) and Craneopsylla minerva minerva (Stephanocircidae), representing 18.9\% ( $N: 175)$. The host Akodon cursor harbored $47.9 \%$ of these fleas. Other six host species were infested by $52.1 \%$ of the remaining fleas. Fleas were found on hosts and in places within the focus not previously reported by the literature.

Key words: Siphonaptera - small rodent fleas - bubonic plague focus - Rio de Janeiro - Brazil

Rodent fleas are biological vectors of bubonic plague, as demonstrated 100 years ago (Simond et al. 1998). Although the order Siphonaptera includes approximately 3,000 species (Lewis 1998) and at least 100 of them can transmit plague, only 59 species were recorded in Brazil up to now (Linardi \& Guimarães 2000). According to Marshall (1981), fleas infest exclusively mammals (94\%) and birds $(6 \%)$. In Brazil, rodents are the preferred hosts, among 12 orders of mammals found to be parasitized (Linardi 1999).

After arriving in Brazil in 1899 by the Santos seaport, State of São Paulo, the plague dispersed in rural zones, exhibiting periodicity as a wild enzootic and rural zoonosis due to the persistence in natural foci in the northeast and southeast Brazilian regions (Freitas 1969). Within the southeast region there is a focus located in the Serra dos Órgãos mountain range which, although not being the most important focus in Brazil, has been of great scientific interest due to its geographic location.

Supported by Brazilian National Health Foundation. +Corresponding author. Fax: +55-21-590.3545. E-mail: rwcar@uol.com.br or raicar@ioc.fiocruz.br

${ }^{++}$Research fellow $\mathrm{CNPq}$

Received 1 August 2000

Accepted 8 February 2001
Due to two human plague deaths recorded, studies in this focus have been intensified since 1967. Serologic surveys by hemaglutination demonstrated the circulation of Yersinia pestis among small rodents and dogs (Almeida et al. 1985, Vieira et al. 1994). Excepting the reports of fleas in Teresópolis, State of Rio de Janeiro (Gomes 1969), the potential vectors of the plague in this area have been poorly studied and fleas have been misidentified. The present study reviews the flea fauna and verify the abundance of fleas on hosts from the focus of Serra dos Órgãos mountain range, State of Rio de Janeiro.

\section{MATERIALS AND METHODS}

Rodents were trapped in the municipalities of Nova Friburgo, Sumidouro and Teresópolis, between November 1995 and October 1997. The study areas are constituted by Atlantic forest of super humid tropical climate, presenting a high pluviometric index $(2250 \mathrm{~mm} / \mathrm{year})$, without dry months and with mean temperature in the summer of $22^{\circ} \mathrm{C}$ and minimum daily average in the winter varying from 15 to $0^{\circ} \mathrm{C}$ (IBGE 1992, Sepla 1996). The study area comprises a polygon which includes 29 study points (Figure), according to the bubonic plague control program criteria from the Brazilian National Health Foundation (Ministério da Saúde 1994).

Rodents were captured during 24 field phases, using 50 live traps in each field phase, baited with 

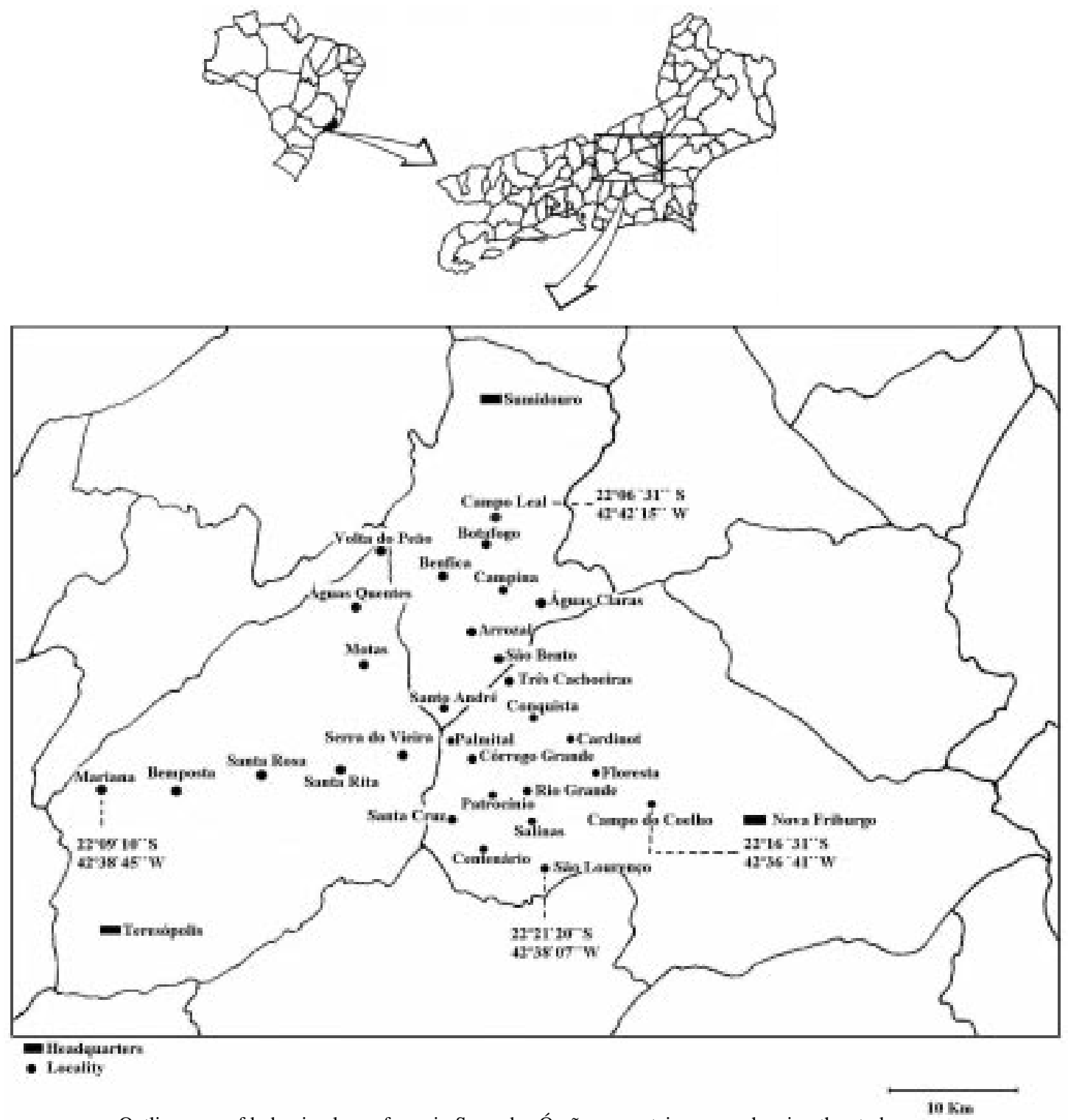

Outline map of bubonic plague focus in Serra dos Órgãos mountain range, showing the study area.

corncobs, during four consecutive nights/phase, investigating four different localities in peridomiciliary area in a week by month. The trapping effort consisted of 4,800 trap-nights. The criteria of choice of the collecting points were that proposed by the Ministério da Saúde (1994) resulting in different trapping success to each place. They were identified based on morphology and karyotypes, following the nomenclature proposed by Musser and Carleton (1993) and the karyotypes according to Yonenaga et al. (1974) to yield precise host identifications.

After anesthetizing the rodents with ether, the fleas were recovered by combing and brushing. After preservation in $70^{\circ}$ ethanol they were mounted on slides for taxonomic identification. Voucher specimens of fleas were deposited in the Laboratory of Ixodides of the Oswaldo Cruz Institute. Skin and skulls of the rodents are deposited in the National Museum, Rio de Janeiro, Brazil.

\section{RESULTS AND DISCUSSION}

In total, 924 flea specimens representing 11 species were taken from 601 small rodents, being $149(24.8 \%)$ of two commensal species and 452 (75.2\%) of eight wild species (Table I).

Rodents were identified according to the nomenclature proposed by Musser and Carleton (1993) representing the following species and respective karyotypes: Akodon cursor (Winge), 


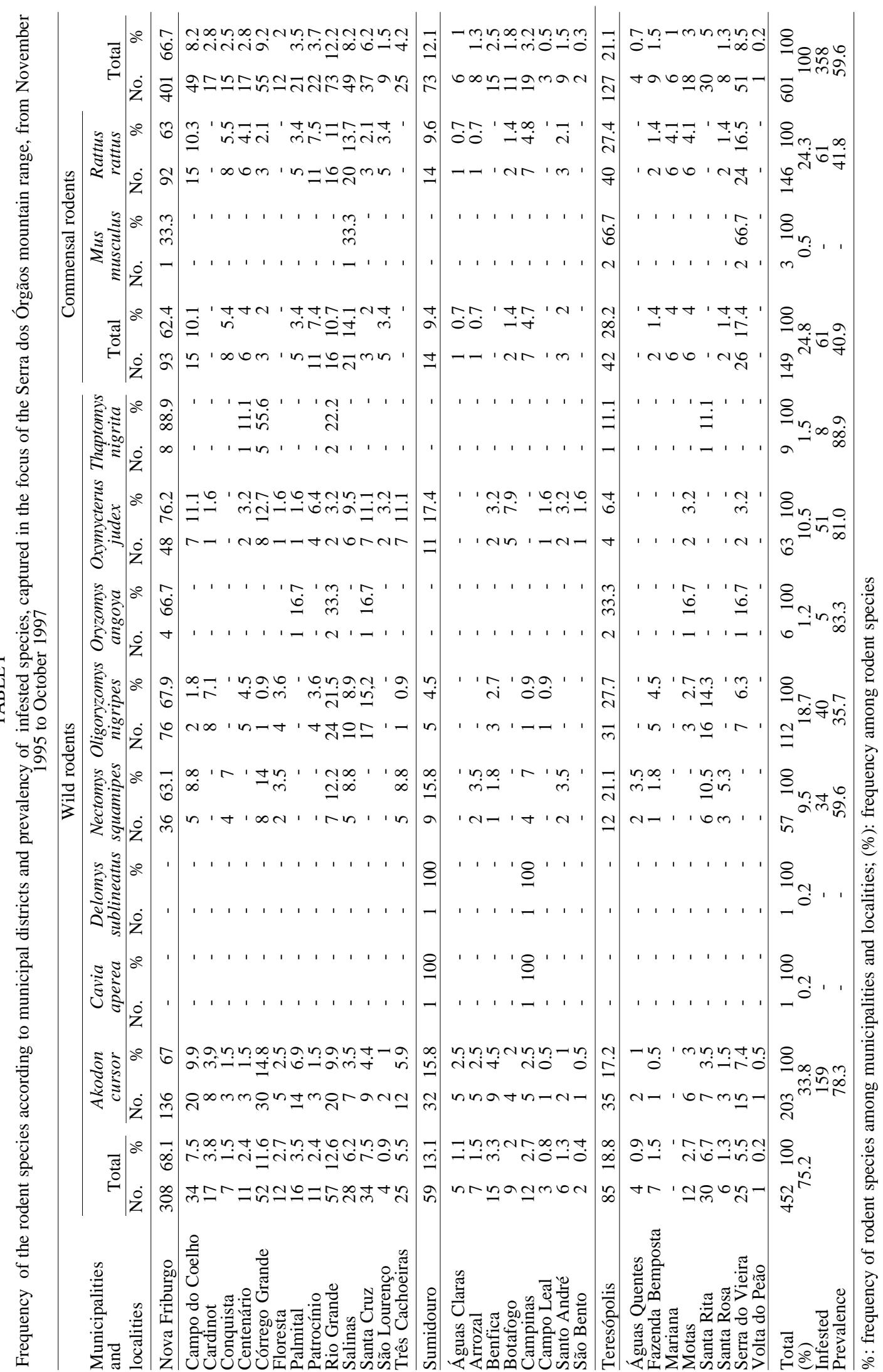


$2 \mathrm{n}=14, \mathrm{FN}=18$; Cavia aperea aperea (Erxleben), karyotype not mounted; Delomys sublineatus (Thomas), karyotype not mounted; Nectomys squamipes (Brants), $2 \mathrm{n}=56, \mathrm{FN}=56$; Oligoryzomys nigripes (Olfers), 2n=62, FN=82; Oryzomys angoya (=Oryzomys ratticeps) (Hensel), $2 \mathrm{n}=58, \mathrm{FN}=60$; Oxymycterus judex Thomas, $2 \mathrm{n}=54, \mathrm{FN}=62$; Thaptomys nigrita (Lichstenstein), $2 \mathrm{n}=52, \mathrm{FN}=52$; Mus musculus brevirostris (Waterhouse) and Rattus rattus (L.) (Table I).

The prevalences are given in Table I. T. nigrita was the most infested host with $88.9 \%$ in spite of the low intensity (1.95) (Table III). It was followed by $O$. angoya, $O$. judex, A. cursor, $N$. squamipes, $R$. rattus and $O$. nigripes respectively. Due to the low number of hosts captured, C. aperea, D. sublineatus and $M . m$. brevirostris were not infested.

The differences of infestation between wild and commensal rodents were highly significant $\left(\chi^{2}=28.53, p<0.01\right)$. When considering each pair of rodents in samples with more than 50 specimens collected, also were highly significant $(\mathrm{p}<0.01)$ the differences between: $A$. cursor and $N$. squamipes $\left(\chi^{2}=8.11\right)$, A. cursor and $O$. nigripes $\left(\chi^{2}=56.30\right)$, A. cursor and $R$. rattus $\left(\chi^{2}=48.66\right), O$. nigripes and $O$. judex $\left(\chi^{2}=33.04\right), O$. judex and $R$. rattus $\left(\chi^{2}=27.09\right)$. Differences between $N$. squamipes and $O$. judex $\left(\chi^{2}=6.55\right), N$. squamipes and $R$. rattus $\left(\chi^{2}=5.24\right)$, evidenced as significant $(\mathrm{p}<0.05)$.

Siphonaptera nomenclature followed the proposal of Johnson (1957) and the revision of the subfamily Rhopalopsyllinae is according to the nomenclature proposed by Linardi and Guimarães (1993) representing the following family and species: Ctenophthalmidae, Adoratopsylla (Adoratopsylla) antiquorum antiquorum (Rothschild); Pulicidae, Ctenocephalides felis felis (Bouché), Pulex irritans L., Xenopsylla cheopis (Rothschild); Rhopalopsyllidae, Polygenis (Neopolygenis) atopus (Jordan and Rothschild), Polygenis (Neopolygenis) pygaerus (Wagner), Polygenis (Neopolygenis) pradoi (Wagner), Polygenis (Polygenis) rimatus (Jordan), Polygenis (Polygenis) roberti roberti (Rothschild), Polygenis (Polygenis) tripus (Jordan); Stephanocircidae, Craneopsylla minerva minerva (Rothschild) (Table II).

Flea species and their distribution by municipalities are shown on Table II. Although only seven species have been found in Teresópolis, other six species of fleas were previously recorded in that municipality (Gomes 1969). So, all the fleas collected in Nova Friburgo and Sumidouro constitute new findings for those municipalities.

$P$. rimatus was observed in all three municipalities, representing more than $40 \%$ of the total samples. It was followed by $P$. pradoi and $P$. atopus, respectively. C. minerva was found in circa
$20 \%$ of the samples. According to the literature, species of Polygenis are able to maintain plague among wild rodents (Brasil et al. 1989). This finding clearly shows that these species would represent the potential vectors of plague in this focus (Table II).

Species of fleas and their respective hosts are given in Table III. The mean number (intensity) of fleas per host $(924 / 601=1.54)$ (Table III) was higher than the ones previously reported in other habitats in Brazil: 0.15 from Caatinga scrub forest in Brazilian northeast (Guimarães 1972) and 0.29 to 0.64 from Araucaria forest in State of Paraná (Barros et al. 1993, Barros-Battesti et al. 1998). In the Atlantic forest, this number was around 0.30 from Guaraqueçaba in State of Paraná (Bicho et al. 1999), 0.93 from Caratinga (Botelho \& Linardi 1980); 1.06 from Juiz de Fora, both in the State of Minas Gerais (Linardi et al. 1987); 2.85 from Salesópolis, State of São Paulo (Linardi 1977) and 3.6 from Angra dos Reis, State of Rio de Janeiro (Guitton et al. 1986), in spite of methodological differences and capture efforts.

The following data represent new host records: $P$. irritans from $O$. judex, $P$. r. roberti from $T$. nigrita, $P$. atopus from $O$. judex and $R$. rattus, $P$. pygaerus from $O$. judex and T. nigrita, and $C$. m. minerva from $R$. rattus.

The interchange between fleas of wild and commensal rodents is an important parameter for studies concerning the epidemiology of plague, since, in this pathway, man can acquire it through flea bites. Species of Rhopalopsyllidae, Stephanocircidae and Ctenophthalmidae are frequently found on wild rodents, differently from the species of Pulicidae which infest mainly commensal rats and other domestic hosts (Azad et al. 1997). Nine hundred and ten out of 924 fleas collected were wild fleas and 14 cosmopolitan fleas (Table III). Among the wild fleas, 804 (88.4\%) were found on wild rodents and $106(11.6 \%)$ on commensal rats. Otherwise, while nine of the cosmopolitan fleas were observed on commensal rats (64.3\%), only five were found on wild rodents $(35.7 \%)$. So, in this interchange, wild fleas are most common on commensal rats, rather than cosmopolitan fleas on wild rodents, as demonstrated by Guimarães (1972) in the Brazilian northeast (Table III).

\section{ACKNOWLEDGMENTS}

To the staff of the Plague surveillance laboratory, State of Rio de Janeiro, the National Health Foundation, for the aid in the collections and rodent captures, to Paulo Cesar de Azevedo Silveira for the drawing of the used map, to Silvia Cristina Barbosa da Silva for the assembly and identification of fleas and to Guilherme Franco Netto and Cibele Rodrigues Bonvicino for the revision of the text. 
TABLE II

Number of flea species according to municipal districts, captured in the focus of bubonic plague of the Serra dos Órgãos mountain range, from November 1995 to October 1997

\begin{tabular}{|c|c|c|c|c|c|c|c|c|c|c|c|c|c|}
\hline \multirow{3}{*}{$\begin{array}{ll}\text { Municipalities } & \text { Cte } \\
\text { and } & A \\
\text { localities } & a\end{array}$} & \multicolumn{13}{|c|}{ Families and species of fleas } \\
\hline & Ctenophthalmidae & \multicolumn{3}{|c|}{ Pulicidae } & \multicolumn{6}{|c|}{ Rhopalopsyllidae } & \multirow{2}{*}{$\frac{\text { Stephanocircidae }}{\begin{array}{c}\text { Craneopsylla } \\
\text { minerva }\end{array}}$} & \multicolumn{2}{|c|}{ Total } \\
\hline & $\begin{array}{l}\text { Adoratopsylla } \\
\text { a. antiquorum }\end{array}$ & $\begin{array}{l}\text { Ctenocephalides } \\
\text { f. felis }\end{array}$ & $\begin{array}{l}\text { Pulex } \\
\text { irritans }\end{array}$ & $\begin{array}{l}\text { Xenopsylla } \\
\text { cheopis }\end{array}$ & $\begin{array}{l}\text { Polygenis } \\
\text { atopus }\end{array}$ & $\begin{array}{l}\text { Polygenis } \\
\text { pygaerus }\end{array}$ & $\begin{array}{l}\text { Polygenis } \\
\text { pradoi }\end{array}$ & $\begin{array}{l}\text { Polygenis } \\
\text { rimatus }\end{array}$ & $\begin{array}{l}\text { Polygenis } \\
\text { roberti }\end{array}$ & $\begin{array}{c}\text { Polygenis } \\
\text { tripus }\end{array}$ & & No. & $\%$ \\
\hline Nova Friburgo & 1 & 4 & 2 & 6 & 100 & 17 & 129 & 249 & 1 & - & 100 & 609 & 66 \\
\hline Campo do Coelho & - & - & - & 3 & 14 & 1 & 12 & 30 & - & - & 6 & 66 & 7.1 \\
\hline Cardinot & - & - & - & - & 4 & - & - & 16 & - & - & 18 & 38 & 4.1 \\
\hline Conquista & - & - & - & - & 1 & - & 2 & 2 & - & - & 2 & 7 & 0.8 \\
\hline Centenário & - & - & - & - & 6 & 3 & 2 & 16 & 1 & - & 4 & 32 & 3.5 \\
\hline Córrego Grande & 1 & - & - & 1 & 22 & 11 & 49 & 64 & - & - & 18 & 166 & 18 \\
\hline Floresta & - & - & - & - & 1 & - & 3 & 1 & - & - & 2 & 7 & 0.8 \\
\hline Palmital & - & - & - & 2 & 3 & - & 2 & 13 & - & - & 16 & 36 & 3.9 \\
\hline Patrocínio & - & - & - & - & 1 & - & 2 & 3 & - & - & 1 & 7 & 0.8 \\
\hline Rio Grande & - & 2 & 1 & - & 31 & 1 & 22 & 34 & - & - & 30 & 121 & 13 \\
\hline Salinas & - & 2 & 1 & - & 4 & - & 5 & 20 & - & - & - & 32 & 3.5 \\
\hline Santa Cruz & - & - & - & - & 3 & 1 & 8 & 13 & - & - & 1 & 26 & 2.8 \\
\hline São Lourenço & - & - & - & - & - & - & 6 & 28 & - & - & - & 34 & 3.7 \\
\hline Três Cachoeiras & - & - & - & - & 10 & - & 16 & 9 & - & - & 2 & 37 & 4 \\
\hline Sumidouro & - & - & - & - & 12 & 5 & 33 & 61 & - & - & 39 & 150 & 16 \\
\hline Águas Claras & - & - & - & - & - & - & 7 & 8 & - & - & 3 & 18 & 1.9 \\
\hline Arrozal & - & - & - & - & 11 & - & $r$ & 19 & - & - & 4 & 34 & 3.7 \\
\hline Benfica & - & - & - & - & - & - & 15 & 7 & - & - & 16 & 38 & 4.1 \\
\hline Botafogo & - & - & - & - & 1 & 3 & 2 & 7 & - & - & 12 & 25 & 2.7 \\
\hline Campinas & - & - & - & - & - & - & 5 & 1 & - & - & - & 6 & 0.6 \\
\hline Campo Leal & - & - & - & - & - & - & - & 3 & - & - & - & 3 & 0.3 \\
\hline Santo André & - & - & - & - & - & - & 3 & 14 & - & - & 1 & 18 & 1.9 \\
\hline São Bento & - & - & - & - & - & 2 & 1 & 2 & - & - & 3 & 8 & 0.9 \\
\hline Teresópolis & - & - & - & 2 & 27 & 3 & 23 & 72 & - & 2 & 36 & 165 & 18 \\
\hline Águas Quentes & - & - & - & - & 2 & - & 1 & 5 & - & - & 1 & 9 & 1 \\
\hline Fazenda Bemposta & - & - & - & - & 2 & - & - & - & - & - & 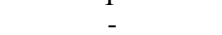 & 2 & 0.2 \\
\hline Mariana & - & - & - & - & - & - & 1 & 2 & - & - & - & 3 & 0.3 \\
\hline Motas & - & - & - & - & 10 & - & 5 & 20 & - & 2 & 16 & 55 & 6 \\
\hline Santa Rita & - & - & - & - & 9 & 1 & 2 & 18 & - & - & 1 & 31 & 3.4 \\
\hline Santa Rosa & - & - & - & - & 1 & 2 & 7 & 10 & - & - & 4 & 24 & 2.6 \\
\hline Serra do Vieira & - & - & - & 2 & 3 & - & 7 & 16 & - & - & 13 & 41 & 4.3 \\
\hline Volta do Pião & - & - & - & - & - & - & - & 1 & - & - & 1 & 2 & 0.2 \\
\hline Total & 1 & 4 & 2 & 8 & 139 & 25 & 185 & 382 & 1 & 2 & 175 & 924 & 100 \\
\hline$(\%)$ & 0.1 & & 1.5 & & & & 79 . & & & & 18.9 & & \\
\hline
\end{tabular}

$\%$ : frequency of fleas in municipalities and in localities; $(\%)$ : frequency of flea families 


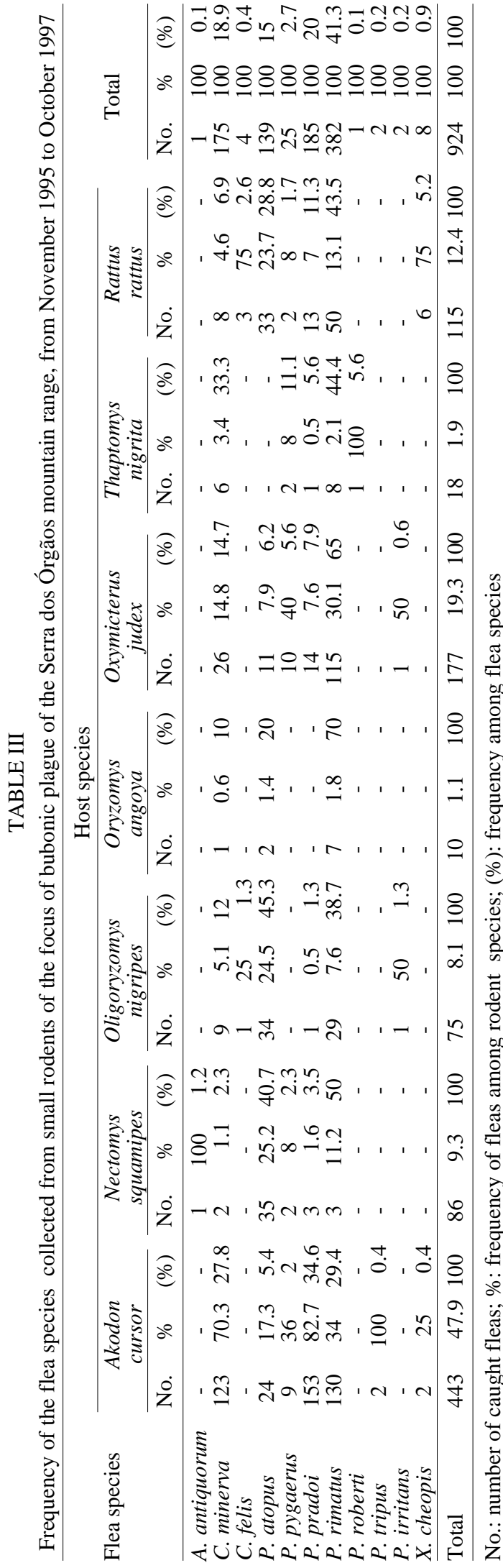

\section{REFERENCES}

Almeida AMP, Brasil DP, Melo MEB, Nakasaua M, Almeida CR 1985. Demonstração de atividade pestosa no foco da Serra dos Órgãos (Rio de Janeiro, Brasil) no período de 1983 a 1984, através de exames sorológicos em roedores. Rev Microbiol São Paulo 16: 280-281.

Azad AF, Radulovic S, Higgins JA, Norden BH, Troyer JM 1997. Flea-borne rickettsioses: ecologic considerations. Emerging Dis 3: 319-327.

Barros DM, Linardi PM, Botelho JR 1993. Ectoparasites of some wild rodents from Paraná State, Brazil. J Med Entomol 30: 1068-1070.

Barros-Battesti DM, Arzua M, Linardi PM, Botelho JR, Sbalqueiro IJ 1998. Interrelationship between ectoparasites and wild rodents from Tijucas do Sul, State of Paraná, Brazil. Mem Inst Oswaldo Cruz 93: 719725.

Bicho CL, Ribeiro PB, Nascimento AP, Sbalqueiro IJ 1999. Siphonaptera de roedores silvestres em Guaraqueçaba, Paraná, Brasil. Entomologia y Vectores 6: 53-62.

Botelho JR, Linardi PM 1980. Alguns ectoparasitos de roedores silvestres do município de Caratinga, Minas Gerais, Brasil. I. Relações pulga/hospedeiro. Revta Bras Ent 24: 127-30.

Brasil DP, Carvalho FG, Almeida CR, Almeida AMP 1989. Pesquisa da infecção natural por Yersinia pestis, em pulicídeos provenientes de focos pestosos do nordeste do Brasil. Rev Soc Bras Med Trop 22: 177 181.

Freitas CA 1969. Peste - Algumas considerações sobre sua epidemiologia e profilaxia. Rev Bras Malariol Doen Trop 21: 673-688.

Gomes AC 1969. Pulgas colhidas em residências e sobre pequenos animais de algumas áreas do Brasil. Rev Bras Malariol Doen Trop 21: 775-780.

Guimarães LR 1972. Contribuição à epidemiologia da peste endêmica no nordeste do Brasil e estado da Bahia. Estudo das pulgas encontradas nessa região. Rev Bras Malariol Doen Trop 24: 95-63.

Guitton N, Araújo Filho NA, Sherlock IA 1986. Ectoparasitos de roedores e marsupiais no ambiente silvestre da Ilha Grande, Estado do Rio de Janeiro, Brasil. Mem Inst Oswaldo Cruz 81: 233-234.

IBGE 1992. Manual Técnico da Vegetação Brasileira. Manuais técnicos em Geociências, IBGE, Rio de Janeiro, $92 \mathrm{pp}$.

Johnson PT 1957. A classification of the Siphonaptera of South America with descripitions of new species. Mem Ent Soc Wash 5: 1-290.

Lewis R 1998. Résumé of the Siphonaptera (Insecta) of the world. J Med Entomol 35: 377-389.

Linardi PM 1977. Relações pulga/roedores observadas nos municípios de Salesópolis e Itapetininga, SP. Bol Mus Hist Nat UFMG Zool 23: 1-25.

Linardi PM 1999. Siphonaptera. In CRF Brandão, EM Cancello (eds), Biodiversidade do Estado de São Paulo, Brasil. 5. Invertebrados Terrestres, USP/ Fapesp, São Paulo, p. 265-275.

Linardi PM, Guimarães LR 1993. Systematic review of genera and subgenera of Rhopalopsyllinae (Sipho- 
naptera: Rhopalopsyllidae) by phenetic and cladistic methods. J Med Entomol 30: 161-170.

Linardi PM, Guimarães LR 2000. Sifonápteros do Brasil, Editora Museu de Zoologia, USP/Fapesp, São Paulo, 291pp.

Linardi PM, Teixeira VP, Botelho JR, Ribeiro LS 1987. Ectoparasitos de roedores em ambientes silvestres do município de Juiz de Fora, Minas Gerais, Brasil. Mem Inst Oswaldo Cruz 82: 137-139.

Marshall AG 1981. The Ecology of Ectoparasitic Insects, Academic Press, London, 459 pp.

Ministério da Saúde 1994. Controle da Peste-Normas Técnicas, Fundação Nacional de Saúde, Brasil, 124 pp.

Musser GG, Carleton, 1993. Family Muridae. In DE Wilson, DM Reeder (eds), Mammal Species of the
World. A Taxonomic and Geographic Reference, Smithsonian Press, Washington, p. 501-755.

Sepla 1996. Anuário Estatístico do Estado do Rio de Janeiro, 1995-1996, Secretaria de Planejamento do Estado do Rio de Janeiro, Rio de Janeiro, p. 279282.

Simond M, Godley ML, Mouriquand PDE 1998. PaulLouis Simond and his discovery of plague, transmission by rat fleas: a centenary. J Royal Soc Med 91: 101-104.

Vieira JBF, Almeida AMP, Almeida CR 1994. Epidemiologia e controle da peste no Brasil. Rev Soc Bras Med Trop 27: 351-358.

Yonenaga Y, Frota-Pessoa O, Kasahara S, Almeida EJC 1974. Cytogenetic studies on Brazilian rodents. $\mathrm{Ci}$ Cult 28: 202-211. 